\title{
A GAZDASÁGI-POLITIKAI ÁTMENET REGIONÁLIS HATÁSAINAK VIZSGÁLATA A VISEGRÁDI ORSZÁGOKBAN 1995-TŐL 2006-IG
}

\author{
(Investigation of the Regional Impacts of the Economic-Political \\ Transition in the Visegrád Countries from 1995 to 2006)
}

\section{KUTTOR DÁNIEL}

\begin{abstract}
Kulcsszavak:
Visegrádi Négyek gazdasági-politikai átmenet regionális egyenlötlenségek

Az 1980-as, 1990-es évek fordulójának világpolitikai eseményei új feltételeket teremtettek Kelet-KözépEurópa számára, ami lehetōvé tette a térség államainak nyugati reorientációját. A cikk az elmúlt két évtized politikai-gazdasági átmenetének területi hatásaival foglalkozik az ún. „visegrádi országokon” (Csehország, Lengyelország, Magyarország, Szlovákia) belül. A társadalom és a gazdasági tevékenységek térbeli elhelyezkedésében tapasztalható egyenlötlenségek leírása, okainak feltárása áll a kutatás fókuszában. Ennek érdekében a regionális diszparitások több szempontú számszerüsitésére, valamint a makro- és mikrogazdasági összefüggések azonosítására kerül sor. A tanulmány a vonatkozó térgazdaságtani elméletek szintetizálására is vállalkozik, külön figyelmet szentelve a telephelyekre, a gazdasági növekedésre, a konvergencia-divergencia jelenségére vonatkozó teóriáknak.
\end{abstract}

\section{Bevezetés}

Napjainkban a területi egyenlötlenségek vizsgálatával, a regionális konvergenciadivergencia összefüggéseivel foglalkozó kutatások nagy érdeklődésre tartanak számot, különösen az Európai Unióban. Ennek a felfokozott figyelemnek az alapvetö okai:

- Az integrációban résztvevő́k köre a közelmúltban, több fázisban bövült, ezáltal a heterogenitás korábban nem látott mértéket öltött. A fejlettségbeli diverzifikáció mérséklésének növekvő pénzügyi igénye maga után vonta a regionális politika újragondolásának, állandó monitorizálásának szükségességét és az összetett konvergencia-vizsgálatokat.

- Az Európai Unió tagállamai és régiói egyre élesedö versenyhelyzetbe kerülnek a regionális és globális piacokon. Az erőforrások birtoklásáért folyó küzdelem az Unión belül, szupranacionális szinten is életre hívta a közösségi innovációs politikát; felértékelte a humántőke, a tudás és a technológia térbeli megjelenésével, terjedésével kapcsolatos elemzéseket.

Kelet-Közép-Európa lokális és globális pozíciója alapvetően és gyorsan változott meg az elmúlt két évtizedben. Az átmenet nem hagyta érintetlenül a térség politikaitársadalmi rendszereit, valamint a gazdasági erőforrások és tevékenységek területi 
eloszlását is jelentősen módosította. Következésképpen kontinensünk e része egyedi lehetöséget kínál a területi folyamatok vizsgálatára, modellezésére (Illés 2002).

Az Európát megosztó vasfüggöny lebomlása lehetővé tette a kelet-közép-európai országok számára a nyugat-európai és az észak-atlanti gazdasági-politikai-védelmi rendszerekbe történö integrációt, amely hozzájárult a tartós demokratizálódáshoz és globalizálódáshoz. A kilencvenes évek közepétől a dinamikus konvergenciának köszönhetően, a fejlett észak- és nyugat-európai országokhoz viszonyítva jelentős mértékben javult a térség államainak makroszintủ szociális-gazdasági pozíciója. Ugyanakkor a nemzeti szintü, reál konvergencia prioritása a korábbi keleti blokk országaiban dominánsan megelözte a szociális esélyegyenlöség, a gazdasági kohézió, a területi kiegyenlités célkitüzéseit (Maurel 2006). Ennek következtében a kilencvenes évek elejétől napjainkig az egyenlötlenségek nagyarányú növekedése ment végbe. A területi diszparitások jelenlegi formájának és nagyságának fennmaradása a hátrányos helyzetủ területek tartós leszakadásához vezethet a jövőben, ami a szociális feszültségek fokozódását, gazdasági kiszolgáltatottság, alárendeltség, illetve növekedési kényszerpályák kialakulását eredményezheti.

Az Európai Unió kohéziós és strukturális pénzügyi forrásainak elérhetővé válása bővítette a területi diszparitások csökkentésére felhasználható pénzügyi eszközök körét és mértékét. A források megjelenése azonban újból felvetette a területfejlesztök örök, „hatékonyság-növelés versus területi kiegyenlités” dilemmáját. Az ellentmondás feloldása a támogatások olyan arányú és szerkezetủ felosztásával lehetséges, amely egyfelöl hozzájárul a területi nivellálódáshoz, másfelől a fejlett térségek növekedési potenciálját, versenyképességét is megörzi. Ehhez elengedhetetlen $a$ térség teljes körü, több szempontú, nemzeti és regionális szintü (szubnacionális) vizsgálata, az erős és gyenge pontok, a veszélyek és lehetőségek feltárása, valamint a kialakult egyenlötlenségek változásainak, okainak elemzése.

Kelet-Közép-Európa kiterjedt és sokszínủ történelmi makrorégióján belül találhatók az ún. Visegrádi Együttmüködés tagállamai (Csehország, Lengyelország, Magyarország, Szlovákia), amelyek több vonatkozásban hasonlóságot mutatnak.

A tanulmányban a Visegrádi Négyek gazdasági egyenlötlenségeinek részletes vizsgálatára vállalkoztunk; amellyel adalékot kívántunk szolgáltatni az Európai Unió térszerkezetével foglalkozó kiterjedt szakirodalomhoz.

\section{A kutatás célja és módszertana}

Munkánk során az alábbi kérdésekre kerestïk a választ:

- Milyen térgazdaságtani elméletek adaptálhatók, illeszthetők a Visegrádi Négyek országaiban az elmúlt két évtizedben lezajlott területi folyamatokra?

- Létezik-e speciális elméleti modell, illetve szabályrendszer, amely leképezi az átmeneti gazdaságokban az egyenlőtlenségek térbeli és időbeli változását?

- Hogyan ment végbe a régióalkotás, a regionalizmus folyamata az érintett négy országban? 
- Milyen regionális politikai célokat és eszközöket definiáltak a döntéshozók a területi egyenlötlenségek mérséklésének érdekében?

- Milyen mértékben alakította át a visegrádi országok térszerkezetét a tervutasításos gazdaságtervezésről, -szervezésről a piaci alapokra történő átállás?

- Milyen hatást gyakorolt a gazdasági nyitottság fokozódása a Visegrádi Négyek területi diszparitásainak alakulására?

- Miként csoportosithatók a régiók földrajzi elhelyezkedésük, gazdaságitársadalmi adottságaik, infrastrukturális ellátottságuk szerint?

- Hogyan változtak a szomszédsági kapcsolatok (szomszédsági kölcsönhatások) a Visegrádi Négyek régiói esetében?

A vizsgált országok (Csehország, Lengyelország, Magyarország, Szlovákia) az elmúlt évszázadok során, döntỏ részben egy távolabbi politikai-gazdasági centrum vonzáskörzetéhez tartoztak. E logika jelölte ki vizsgálatunk időhorizontját is, amely úgy fogalmazható meg röviden, hogy a „két unió közötti” állapot. Azaz a Varsói Szerződés, a Kölcsönös Gazdasági Segítség Tanácsa, valamint a Szovjetunió 1991-es felbomlásától a Visegrádi Négyek 2004-es európai uniós csatlakozásáig terjedő időszak.

A rendelkezésre álló országos adatok lehetővé tették az átmenet teljes (1990-es évek elejétől, sőt a nyolcvanas évek végétől napjainkig tartó) időszakának lefedését; azonban szubnacionális szinten ez a teljesség a megbízható, egymással kompatibilis regionális és megyei szintủ adatok hiánya miatt már sérült. Ez a korlát eredményezte, hogy a számszerủ regionális vizsgálatokat az 1995-ös esztendővel kezdtük. A frissebb, 2004-et követő évek adatai ugyanakkor lehetővé tették, hogy az elemzést folytassuk és kimutassuk az európai uniós csatlakozás korai hatásait.

\section{A téma elméleti megközelítése}

A gazdasági eröforrások és tevékenységek földrajzi szempontból egyenlötlen eloszlása vitathatatlan. A területi egyenlőtlenségek a térbeli változások szükségszerü velejárói. Megszüntetésük nem is lehetséges maradéktalanul. Mindezek ellenére az eltérések, különbségek időbeli és térbeli változásának megértése évtizedeken, évszázadokon keresztül inspirálta a földrajztudomány és a közgazdaságtan kutatóit (Illés 2008).

A különféle telephely-elméletek által a gazdasági tevékenységek térbeli eloszlásának vizsgálata hosszabb időtávra tekint vissza. Az első ilyen jellegủ számításokat a 17. század elején végezték, amelyekben matematikai módszerekkel tettek kísérletet egy telep helyének optimális meghatározására, figyelembe véve a nyersanyag beszerzésének és a késztermékek eladásának helyeit. A módszer célja, a piacra jutás költségeinek minimalizálása (Ottaviano-Thisse 2004).

Később, a 19. században $J$. H. von Thünen készített modellt, amellyel rávilágított a mezőgazdasági és ipari tevékenységek térbeli elhelyezkedésének szabályosságára. Annak ellenére, hogy $J$. H. von Thünen nem sokkal az ipari forradalmat követően fogalmazta meg elméletét, meglepő teljességgel és eredetiséggel tette azt. Figyelemre 
méltó, ahogyan írásba foglalta a modern értelembe vett technológiai „spill-over” (túlcsordulás) jelenségét és az iparágak közötti kapcsolatok fontosságát (Edwards 2007).

A telephelyek további összefüggéseivel A. Weber foglalkozott, aki az ipari üzemek optimális helyének megtalálására koncentrált, különös tekintettel a fogyasztópiac, a nyers- és alapanyagok elhelyezkedésére. Később, A. Weber megállapításaira építve E. M. Hoover készítette el az agglomerációs előnyök standard osztályozását, ami összhangban áll a Marshall-féle externáliák rendszerével. Idővel pedig A. Lösch fejlesztette tovább a telephelyre vonatkozó elméleteket azáltal, hogy nem egyedekben, hanem egész térbeli struktúrában gondolkodott; valamint az árakat és piaci viszonyokat nem kívülről determináltnak tekintette, hanem endogén tényezöknek (McCann-van Oort 2009).

Annak ellenére, hogy a földrajztudomány és a közgazdaságtan kutatói hosszabb ideje elemzik az országok és régiók közötti jövedelmi különbségeket, egyértelmü, koherens elméleti háttér, modell nem áll rendelkezésre. Számos, a területi fejlődés és egyenlötlenség mechanizmusait feltárni szándékozó - egymásnak sokszor ellentmondó - hipotézis született. Ezen feltételezések létjogosultsága, igazolása nagyban függ a vizsgált sokaságtól, idöszaktól, az adatok mennyiségétöl és minöségétöl.

A neoklasszikus irányzat a Ricardo-Mill-Smith-féle klasszikus közgazdaságtan örökségére épül, amely szerint a gazdasági észszerüség és a piaci mechanizmusok alapján a termelési tényezők tökéletes mobilitása és áramlása megy végbe, a nagyobb megtérülést nyújtó térségek irányába (Gilpin 2004). A vállalkozás a több profitot, a munkaerő a magasabb bért ígérő lokáció felé áramlik. A tényezők csökkenő határhasznán keresztül a gazdaságban ugyanakkor egy kiigazító mechanizmus müködik, ami az egy före eső jövedelem tekintetében a területi diszparitások hosszú távú kiegyenlítódését eredményezi. $R$. M. Solow szerint a növekedéssel párhuzamosan egyszerüen eltünnek a területi különbségek a tőke- és a munkatényező csökkenő határhaszna miatt. A neoklasszikus elméletet az alapvető feltételezései miatt számos kritikával illetik. Mindezek ellenére az irányzat jelentős hatást gyakorol a regionális fejlödések vizsgálatára és a területpolitikára (Pike-Rodríguez-Pose-Tomaney 2008).

A termelési tényezők, mint extern adottságok használatával való elégedetlenség a neoklasszikus elméletek továbbgondolásához vezetett. A korábban külsőnek, függetlennek tekintett elemek beépítésére törekvő endogén növekedés elméletek középpontjában is a regionális konvergencia-divergencia áll. Az innováció és a technológia, mint termelési tényezönek a modellbe történö bevonását követi a legnagyobb figyelem. Az endogén növekedési modellek megállapításai szerint a régiók eltérö fejlödésének következtében kialakuló területi különbségek tartósan fennállhatnak (Fenyővári-Lukovics 2008). Ennek értelmében a tudás felhalmozása növekvő skálahozadékot eredményez, ami nem hordozza magában a területi egyenlőtlenségek csökkenésére irányuló mechanizmust (Barro 2005).

A másik, jelentős elméleti iskolát, amely a térbeli egyenlötlenségekről a neoklasszikustól eltérö gondolatokat fogalmaz meg, J. M. Keynes neve és munkássága fémjelzi. Építve a neoklasszikus elmélet kritikájára a keynes-i megközelítés a regionális divergenciák megértésére és magyarázatára törekszik. Az irányzat a tényezők 
alul-hasznosítottságára, a keresleti oldal elégtelenségére és az állam gazdasági szerepének meghatározására koncentrál. Annak ellenére, hogy J. M. Keynes koncepciója elsődlegesen országokra vonatkozott, számtalan gondolatát ültették át a regionális gazdaságtan területére. G. K. Myrdal, valamint más neo- és poszt-keynesiánus gondolkodó véleménye alapján a regionális fejlödés fokozza a területi különbségeket (Novák-Papdi 2007).

Az export-bázis elmélet a keynes-i kereslet-központú irányzat egyik típusa. A regionális fejlödésekben megmutatkozó különbségeket a régiók különböző export volumenéből vezeti le. Ennek megfelelően az adott régió outputja iránti külső kereslet határozza meg annak növekedési rátáját. A differenciálódás mechanizmusa abból fakad, hogy a külkereskedelemből származó bevételek először, közvetlenül az exportorientált szektorokban, régiókban generálnak növekedést, és ez a jótékony hatás csak idővel terjed át az alárendelt, nem exportáló ágazatokra, területekre (Kocziszky 2008).

Ehhez kapcsolódóan $N$. Kaldor definiálta a „körkörös vagy kumulatív összefüggések" jelenségét, amelyben feltárta a gazdasági növekedés önfokozódó mechanizmusát. Ez magyarázatot ad a fejlettebb régiók össztermékének gyorsabb, nagyobb mértékü bővülésére, illetve a fejletlenek marginalizálódására, leszakadására (Benedek 2000).

$\mathrm{Az}$ export-bázis elméletet és a Kaldor-féle körkörös összefüggések gondolatát követik az ún. polarizációs irányzatok, amelyek a korábbiaktól eltérően a fejlődésbeli különbségekben, a divergenciákban látják a regionális fejlődés természetét. F. Perroux és J. R. Boudeville dolgozta ki a növekedési pólusok teóriáját, amely szerint éppen az egyensúlytalanságok és az általuk létrehozott pólusok a növekedés hajtóerői, generálói (Kozma 2006).

Idővel újabb és újabb modellek kifejlesztésére került sor. Az új növekedéselméletek már nem éltek a csökkenő (eltünő) határhaszon feltételezésével, különösképpen a humán, a tudás és a közvagyon formáira. Az új kereskedelmi elmélet nem csak elhagyta a csökkenö határhaszon kikötését, hanem bevezette a rendszerbe a szállitási költséget. A földrajzi gazdaságtan a nemzetgazdaságtan prosperitásával, a kereskedelemmel és e két tényező egyenlőtlen helyi és regionális fejlődést befolyásoló hatásával, összefüggéseivel foglalkozik. Az irányzat a keynes-i és kaldori tökéletlen versenyre, a növekvő hozadékokra, a külső megtakarításokra építve, illetve kombinálva ezeket az iparágakon és vállalaton belüli kereskedelem eszméjével, alapvetően kérdőjelezi meg a neoklasszikus elmélet megállapításait (Lengyel-Rechnitzer 2004).

A kilencvenes évek elején jelentek meg P. Krugman munkái, amelyekben új gazdaságföldrajz („New Economic Geography”) néven lényegében elsőként állította központba a gazdasági folyamatok esetében a térbeli meghatározottságot, s ennek révén nemcsak a regionális tudomány megújítását ösztönözte, hanem a közgazdaságtudomány nyitását is a területi összefüggések felé (Varga 2009). A koncepció kidolgozásban P. Krugman mellett M. Fujita és A. Venables játszott döntő szerepet (Fujita-Krugman-Venables 2001).

Az új gazdaságföldrajz vagy másképpen az agglomerációs gazdaságtan (agglomeration economies) abból a megfigyelésből indul ki, hogy a gazdasági tevékenységek térben koncentrálódnak. 
A gazdasági fejlődés és a területi differenciálódás (vagy nivellálódás) közötti összefüggéseket mások annak komplexitásában kísérelték meg feltárni. J. G. Williamson (1965) az országokon belüli fejlettségi különbségeket időben és térben vizsgáló tanulmánya újszerü megközelítést hozott. Az 1965-ben megjelenő munkájában az USA területeit vizsgálta idősoros és keresztmetszeti adatokon keresztül (Nemes Nagy 1998). Megállapítása szerint a területi diszparitások mértéke a jövedelem, illetve a gazdasági fejlettség szintjének függvényében eltéröen, de szabályszerüen változik. Emellett a nemzetgazdasági és a regionális fejlődés kapcsolatával foglalkozik a „trade-off” (váltómozgás) elmélete is, amely kimondja, hogy az agglomerálódás és a regionális egyenlötlenségek változása kölcsönhatásban vannak egymással, időben ciklikusan követik egymást (Meyer-Lackenbauer 2006).

Munkánkra legnagyobb hatást a Barro-féle endogén növekedéselmélet, valamint a polarizációs teóriák gyakorolták. Emellett a számítások a Williamson-féle hipotézist és a váltómozgás jelenségét kívánták tesztelni a Visegrádi Négyek régióira adaptálva.

\section{A diszparitások változásainak számszerüsítése, összefüggéseinek feltárása}

A kutatások során a Visegrádi Négyek regionális szintű, gazdasági egyenlőtlenségeinek vizsgálatát végeztük el. A diszparitások számszerüsítéséhez kiterjedt eszköztár áll rendelkezésre (Dusek 2004; Nemes Nagy 2005; Kocziszky 2007). A munka során arra törekedtünk, hogy a hipotézisek ellenőrzéséhez az egyszerübb matematikai méréstől a komplexebb statisztikai eljárásig minél több módszert alkalmazzunk. Elemzéseinkhez minden esetben a kelet-közép-európai térség harmincöt NUTS 2-es régiójának adatait használtuk fel az 1995-2006-os időtávra kiterjedöen.

A GDP/fö adatok használatával a terjedelem-arány és duálmutató mellett a szóródás és szórás értékekkel számszerüsítettük a regionális differenciálódást. Majd a diszparitások különböző dimenzióit bemutató komponenseket egy komplex mutatószámban ötvöztük.

A sokaság eloszlását box-plot és hisztogramos megjelenítéssel ellenőriztük. A régiók konvergenciáját-divergenciáját szigma és béta eljárással teszteltük.

Az átmeneti időszakban, 1995 és 2006 között a Visegrádi Négyek makroszintü gazdasági növekedésével mezoszintű polarizáció párosult. A nemzeti és regionális területi szinteken egyidejüleg konvergens, illetve divergens folyamatok zajlottak le. Ezáltal a visegrádi országok igazolták a transzformációs időszak növekvő mértékü területi egyenlőtlenségeiről szóló Williamson-féle hipotézist.

A Visegrádi Négyek régióira vonatkozó konvergencia-vizsgálatok cáfolták az endogén növekedéselmélet spontán területi kiegyenlítődésre vonatkozó hipotézisét, ugyanakkor bizonyították a hasonló gazdasági szerkezetü és fejlettségü térségek által formált ,konvergencia klubok” létezését. 


\section{1. ÁBRA}

A Visegrádi Négyek régióinak szóródása jövedelmi helyzetük és növekedési képességük szerint (1999-2006)

(Dispersion of the Regions in Visegrad Four Countries by GDP Growth and GDP per Capita)

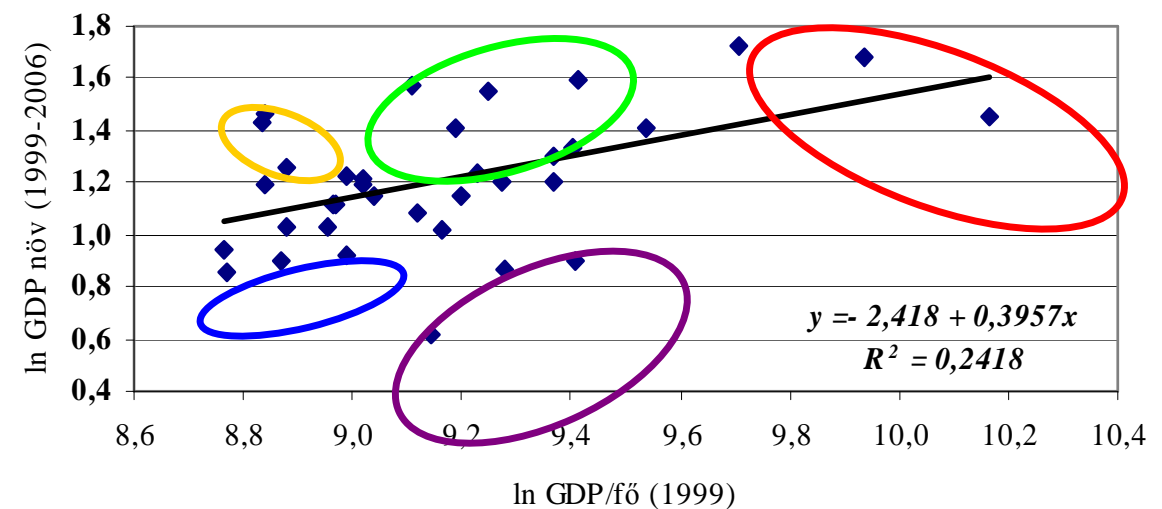

Forrás: Saját szerkesztés.

A továbbiakban arra kerestük a választ, hogy az egyes gazdaságok növekedése és nyitottságának fokozódása, illetve a kormányzatok pénzügyi pozíciója milyen hatással van a területi egyenlőtlenségek változására. Az összefüggések feltárásához láncviszonyszámokat és korreláció-számítást alkalmaztuk a Visegrádi Négyek adataira, az 1995-től 2006-ig terjedő időszakban. A makroszintü adatok vizsgálatával sikerült választ adni arra a kérdésre, hogy miért találhatók a területi polarizáció fokozódásának folyamatán belül eltérő ütemü szakaszok.

A regionális GDP/fö értékek szórásának, valamint a GDP, a külkereskedelmi nyitottság, a müködőtőke-beáramlás és a fizetési mérleg mértékének éves változását és egymáshoz való viszonyát elemeztük. A kapott eredményeket függvények segítségével ábrázoltuk.

A tényezö-vizsgálatok rámutattak a külkereskedelmi nyitás, a müködőtőkebeáramlás és a gazdaság növekedés kölcsönös, egymást gerjesztö hatására; illetve $a$ diszparitások növekedését előidéző következményére. A közvetlen, külföldi beruházások, ezáltal az exportorientált modern gyártási technológiák (beleértve mind a fizikális, mind a szellemi infrastruktúrát) földrajzi megjelenése rendkívül koncentrált volt, így a fejlettségbeli területi egyenlőtlenségek fokozódásának irányában hatott.

$\mathrm{Az}$ alkalmazott időbeli keresztkorreláció-számítás igazolta a fenti megállapítást, ugyanakkor rámutatott egy ,álösszefüggésre” is. Ezek szerint a GDP növekedés területi egyenlőtlenségeket fokozó hatása látszólagos, valójában a müködőtőke és a gazdasági nyitottság polarizációs hatása jelenik meg benne. 


\section{2. ÁBRA}

A visegrádi országok össztermékének és az egy före jutó regionális GDP szórásának alakulása (éves változás \%-ban, 1996-2006)

(Interdependency of the Annual Changes of Total GDP and Regional Dispersion of GDP per Capita in Visegrad Four Countries)

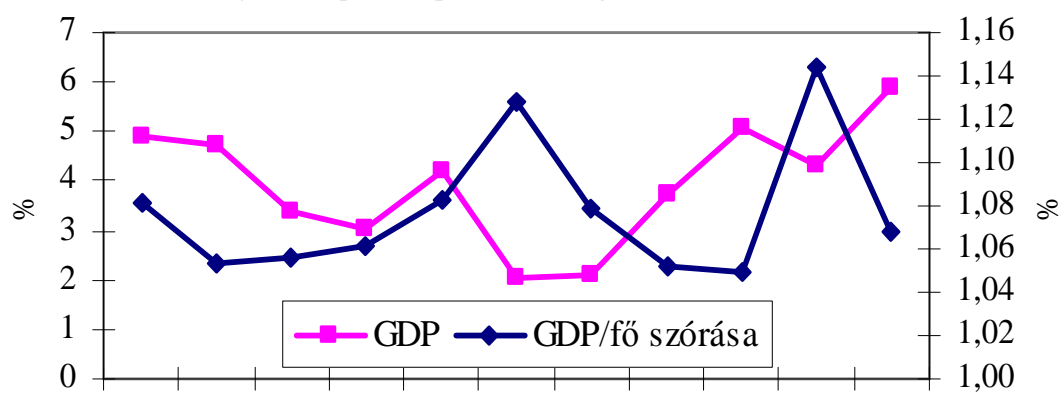

19961997199819992000200120022003200420052006

Év

Forrás: Saját szerkesztés.

A kormányzatok pénzügyi pozícióinak elemzése az előbbiekhez hasonló szoros, egyértelmü kapcsolatot nem mutatott ki. Annyi állapítható meg, hogy a 2000-es esztendőt követő időszak romló fizetési mérlegei beszükítették a kormányzatok mozgásterét a regionális politikák finanszírozása terén, amelyen kisebb mértékben csupán az európai uniós csatlakozás változtatott.

A Visegrádi Négyek globalizálódása és európai uniós integrálódása a gazdasági nyitás fokozódását eredményezte. A külföldi müködőtőke megjelenése és ezzel szoros összefüggésben az exportorientált gazdasági tevékenységek földrajzi kiépülése mind a négy vizsgált országban nagyfokú koncentráltságot mutatott az 1995-2006-os időszak során. A külgazdasági kapcsolatok hangsúlyosabbá válása és a külföldi müködőtőke térnyerése erösítette a regionális differenciálódás, polarizálódás folyamatát.

A regionális diszparitások makrogazdasági összefüggéseinek elemzése igazolta az export-bázis elmélet mechanizmusainak érvényességét a Visegrádi Négyek esetében.

A makroszintü tényezők vizsgálatát követően a regionális adottságok gazdasági növekedést, ezáltal az egyenlőtlenségeket befolyásoló hatásával foglalkoztunk.

A területi egyenlötlenségekre ható tényezők elemzéséhez a lineáris (Pearson-féle), kétoldalú korreláció-számítás módszerét választottuk. A korreláció-számítás a menynyiségi változók közötti összefüggések irányának és erősségének meghatározását tette lehetővé. Két időpontban (2000-ben és 2005-ben) teszteltük, hogy az egy före jutó bruttó hazai termék és a többi mennyiségi változó között milyen természetű kapcsolat áll fenn, illetve az időben miként változott. 
Az alábbi területeket 13 mennyiségi változóval jellemeztük:

- az emberi eröforrás mennyisége és minösége;

- a gazdaság növekedése, mérete és szerkezete;

- az innováció és a tudásgazdaság jelentösége;

- az infrastruktúra sürüsége és minösége.

Az emberi erőforrásra vonatkozó tényezők minden esetben szignifikánsak és erős, illetve közepesen erős kapcsolatot mutattak. Fontosnak tartottuk kiemelni, hogy a vizsgálat során a legerősebb, pozitív kapcsolatot a felsőfokú végzettségüek és a kutatás- és technológia-fejlesztő ágazatokban foglalkoztatottak aránya és az egy főre jutó bruttó hazai termék között találtuk. A kapcsolat intenzitása mindkét esetben növekedett 2000 és 2005 között. Pozitív, ugyanakkor kisebb intenzitású kapcsolatot tártuk fel a kutatás-fejlesztés GDP arányos kiadása, valamint a GDP/fő között.

Emellett Bennett módszert alkalmaztunk a régiók rangsorképzésére (1999-ben és 2006-ban). Az eljárás lehetőséget kínált az egymáshoz viszonyított fejlettségi szintek rögzítésére és a korábban már használt 13 tényező szerepének kimutatására.

A Visegrádi Négyek regionális tényező-vizsgálata hangsúlyozta, sőt kiemelte az emberi erőforrás jelentőségét. Az eredmények alapján a gazdasági növekedés elömozdítása, illetve a hátrányos helyzetű térségek segítése érdekében az emberi erőforrás fejlesztése, tudásszintjének emelése és a munkaerö-piaci feltételek javítása tekinthető a legfontosabb feladatnak. Erre a megállapításra építettük harmadik tézisünket.

A visegrádi országok régiói nagyfokú heterogenitást mutatnak a termelési tényezök tekintetében. A tényezők böséges, illetve szükös rendelkezésre állása befolyásolta a régiók növekedési képességét, ezáltal a regionális egyenlötlenségek alakulását.

A termelési tényezők és a gazdasági fejlettség kapcsolatának vizsgálati eredményei az emberi erőforrásnak, valamint a kutató-fejlesztő tevékenységnek tulajdonítottak kiemelkedö jelentöséget. A korreláció-számítások szerint a fejlettségi rések mértékének csökkentése és a területileg kiegyensúlyozott gazdasági növekedés megvalósitása érdekében elsödleges feladat a humán tőke és a kutatás-fejlesztés eloszlásában mutatkozó regionális különbségek mérséklése.

Ezután a Visegrádi Négyek több szempontú regionális elemzését végeztük el. A régiók csoportosítására több hazai és nemzetközi példa szolgáltat alapot. Az Európai Unió (ESPON), a Világbank, az ENSZ, az OECD is foglalkozik a szubnacionális szint területi egységeinek tipologizálásával (United Nations 2002; European Commission 2008; World Bank 2009).

Esetünkben a csoportképzés szempontjai a következők voltak: a népesség koncentrációja, a gazdaság szerkezete és a régió földrajzi helyzete. Az első esetben a népsürüség és a régió legnépesebb településének népességszámát; a másodikban a munkaerő és a hozzáadott érték szektorális megoszlását használtuk fel.

Emellett azt vizsgáltuk, hogy létezik-e összefüggés az egyes régiók lokációja és fejlettségi szintje között. Ide kapcsolódik az úgynevezett „,nyugat-kelet lejtő” hipotézise, amely szerint minél kedvezőbb geopolitikai (nyugatibb) fekvésü egy térség, 
annál magasabb a fejlettségi szintje (nagyobb a GDP/fö értéke). Ennek teszteléséhez a régiók földrajzi helyzetét és gazdasági fejlettségi mutatóját vetettük össze.

3. ÁBRA

A Visegrádi Négyek régióinak elhelyezkedése a GDP értékük és nyugat-keleti helyzetük alapján 2006-ban (fövárosok adatai nélkül)

(Dispersion of the Regions in Visegrad Four Countries by GDP per Capita and Location [on West-east Axis] in 2006 [Capital Regions Excluded])

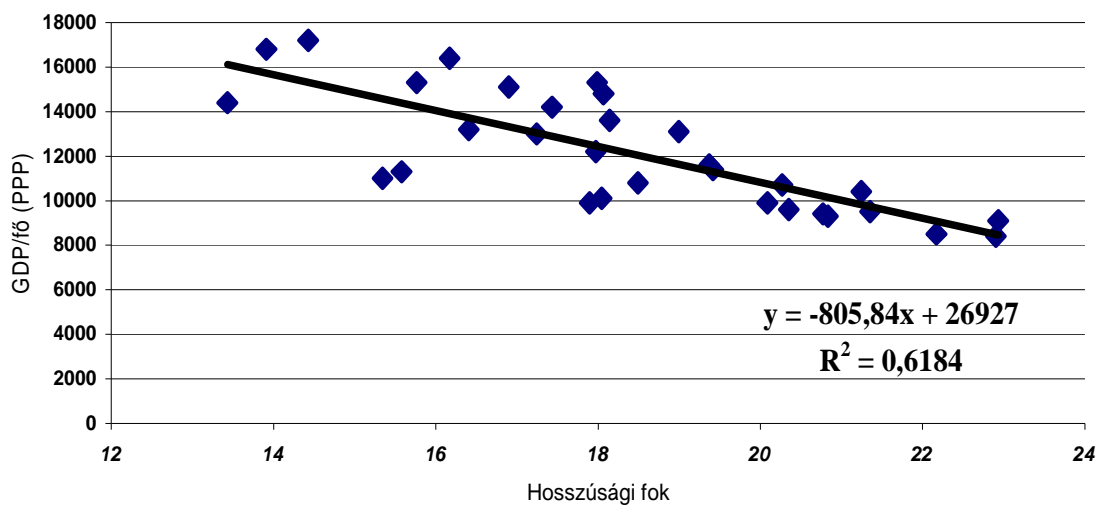

Forrás: Saját szerkesztés.

Az egyes régiócsoportok között feltárt szignifikáns eltérések a centrum-periféria viszonylatában is értelmezhetők. A számok megmutatták, hogy az elmúlt két évtizedben „kinyílt a fejlettségbeli olló” és kritikus mértékủvé vált a „szakadék” a városodott, urbánus, tercierizálódott gazdaságú régiók és a vidéki, rurális, ipariagrár térségek között.

Ezt követően a sokaság elemeinek integrált csoportosítását készítettuik el. A hierarchikus klaszterelemzés módszer egyidejüleg több szempont bevonását teszi lehetővé. Ennek megfelelően 10 változó standardizált (Z érték alapján) értékét használtukfel, a 2006-os esztendő adatai alapján.

A klaszterelemzés során a sokaság egyedeinek egymástól való, euklideszi értelemben vett „távolsága” határozta meg a csoportosítási lehetőséget. A sokaság számának redukálásáról, ezáltal az optimális klaszterszámról az agglomerációs együttható tájékoztatott.

A többtényezős térszerkezet-vizsgálat a Visegrádi Négyeken belül az átmenet hatására (2006-ban) jól azonosítható, elkülöníthető térelemek kialakulását jelezte, amelyeket az alábbiak szerint nevesítettük, illetve jellemeztük röviden:

- $\quad$ Az átmenet nyerteseinek, haszonélvezőinek tekinthető régiók:

- elsődleges haszonélvezők vagy „abszolút nyertesek” csoportja: a dinamikus növekedést felmutató, rugalmas, aktív és képzett munkaerővel, kiterjedt szolgáltató szektorral, fejlett infrastruktúrával és jó elérhetőséggel rendelkező fővárosi régiók. Ez a kategória két klasztert foglal magában 
(1-es és 2-es számú klaszter: Prága-Pozsony, valamint KözépMagyarország).

- másodlagos haszonélvezők vagy „potenciális felzárkózók” csoportja: kedvező geopolitikai helyzetű (nyugati fekvésü) térségek, amelyek urbanizáltak, jelentős és modernizált ipari hagyományokkal és kapacitásokkal, valamint fejlett szolgáltató szektorral bírnak, ezáltal sikeresen kapcsolódtak be az európai munkamegosztásba és értékteremtésbe (3-as számú klaszter).

- $\quad$ Az átmenet veszteseinek tekinthető régiók:

- vesztesek vagy „,veszélyeztetett leszakadók” csoportja: azokat a régiókat jelöli, amelyek földrajzi elhelyezkedése kedvezőtlen, (belső vagy külső) periférikus, ahol a gazdasági szerkezetváltás folyamatban van, ami megmutatkozik a gazdaság hátrányos szektorális megoszlásában és a kedvezőtlen munkaerö-piaci kondíciókban (4-es számú klaszter).

\section{4. ÁBRA}

Régió-klaszterek földrajzi elhelyezkedése (Geographical Location of Regional Clusters)

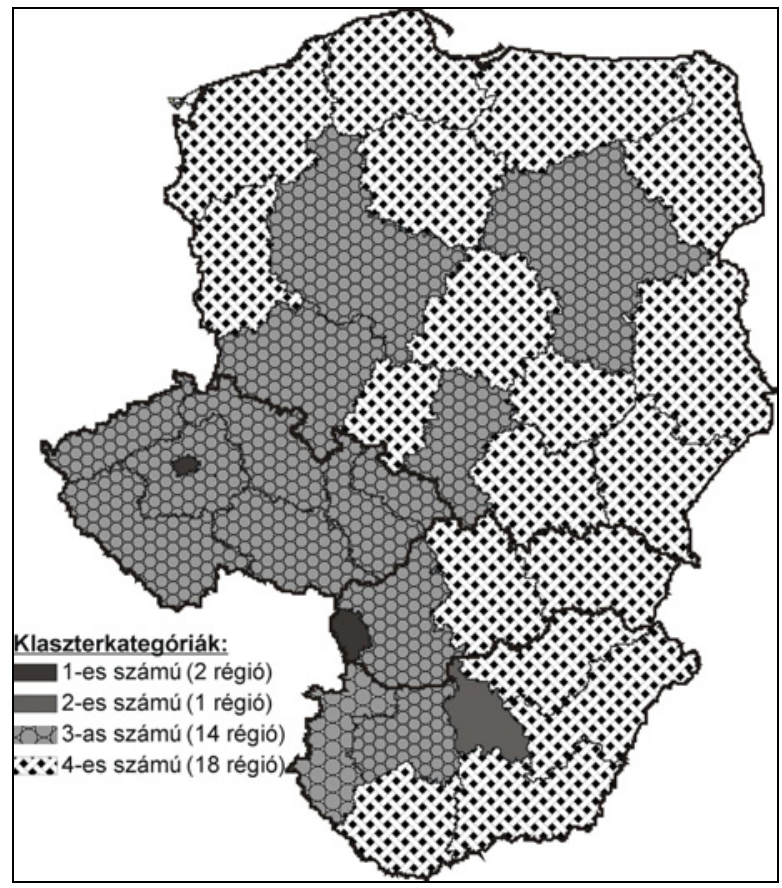

Forrás: Saját szerkesztés.

Az elmúlt két évtized politikai-gazdasági változásai átformálták a visegrádi országok gazdasági, társadalmi térszerkezetét. Az időszak alatt mind a centrum-periféria, mind a nyugat-kelet relációban fokozódtak a térszerkezeti egyensúlytalanságok és egyenlőtlenségek. 
A régiók több szempont alapján történő klaszterizációja lehetővé tette az átmenet nyertes és vesztes térségeinek azonosítását. A fővárosok mellett a diverzifikált gazdasági és munkaerö-piaci szerkezettel bíró, kedvező geopolitikai helyzetü régiók tudtak gyorsabban és hatékonyabban alkalmazkodni a nemzeti és nemzetközi verseny kényszeréhez, illetve az együttmüködés lehetőségéhez.

A szomszédsági hasonulások leírásához a területi autokorrelációt elemeztük, és a határok gazdasági térelválasztó funkcióját vizsgáltuk. Ezen módszerek által az azonos jegyeket felmutató egységek földrajzi csoportosulását kívántuk igazolni, illetve a „fejlettségbeli szakadékokat” azonosítani. A régiók viszonyát és kölcsönhatását a szomszédsági mátrix, a potenciál módszer és a térben súlyozott (késleltetett) GDP/fő értékek számbavétele alapján tettük meg.

A kapott eredmények a Visegrádi Négyek térszerkezetének lényegi módosulását jelezték. A korábban - fejlettség szempontjából - homogénnek tekinthető térségen belül új csomópontok alakultak ki. Míg bizonyos törésvonalak, mint például egyes határszakaszok elvesztették elválasztó funkciójukat, addig máshol új „rések” (különösen a magrégiók határai mentén) jelentek meg.

\section{5. ÁBRA}

Az egyes határszakaszok átlagos fejlettségbeli különbségeinek változása (Changes of Development Gaps along the Different State Borders)

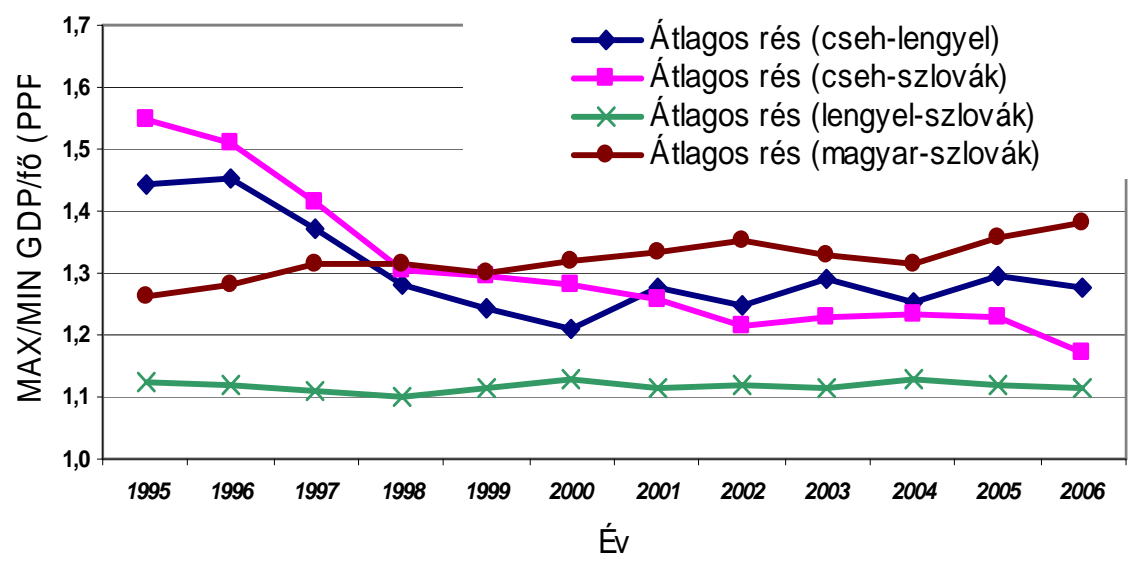

Forrás: Saját szerkesztés EuroStat adatok alapján.

2006-ra kirajzolódó potenciáltérkép alapvető különbséget tett Csehország, Magyarország, Szlovákia, valamint Lengyelország között. Az előbbi három államban inkább a nyugat-kelet tagoltságú térszerkezet alakult ki, erősödött meg; utóbbiban a központ-periféria típusú.

A visegrádi országok régióinak szomszédsági kapcsolatrendszere átalakult az átmenet folyamatainak következtében.

A polarizáció területi hatásaként a legnagyobb mértékü fejlettségbeli rések a központi régiók határai mentén alakultak ki az idöszak végére. Ugyanakkor az országhatárok gazdasági értelemben vett elválasztó, szakadékképzö szerepe csökkent. 
A régiók gazdasági kölcsönhatását modellező potenciálmódszer bizonyította Csehország, Magyarország, Szlovákia térszerkezeteinek hasonlóságát, amelytől Lengyelország érdemben eltér. Elöbbi három ország esetében a nyugat-kelet tagoltság, utóbbinál a centrum-periféria viszony a jellemzőbb.

Végezetül az „új gazdaságföldrajz” elméletéből kiindulva az erőforrások koncentrációját, valamint a növekedési pólusok szerepét és helyzetét vizsgáltuk. Építve a korábbi település-hierarchia vizsgálatának eredményeire a makroregionális és nemzeti hatókörrel, funkciókkal bíró pólusok azonosítását végeztük el. Az eredmények a négy főváros mellett további öt lengyel várost, illetve agglomerációt jelöltek meg, mint potenciális növekedési pólus (Budapest, Varsó, Pozsony, Prága, valamint Gdansk-Gdynia-Sopot, Krakkó, Lódz, Poznan, Wroclaw). Ezt követően a fent nevezett központok gazdasági, társadalmi, tudományos szerepét vizsgáltuk nemzeti és nemzetközi összehasonlításban.

\section{TÁBLÁZAT}

A Visegrádi Négyek bruttó hazai termék (GDP) regionális koncentrációjának mértéke (Changing Regional Concentration of GDP in Visegrad Four Countries)

\begin{tabular}{llc}
\hline & Gini index & $\begin{array}{c}\text { Herfindhal- } \\
\text { Hirschman } \\
\text { index }\end{array}$ \\
\hline 1995 & 0,2971 & 0,0394 \\
1996 & 0,3060 & 0,0403 \\
1997 & 0,3113 & 0,0412 \\
1998 & 0,3148 & 0,0420 \\
1999 & 0,3244 & 0,0431 \\
2000 & 0,3246 & 0,0431 \\
2001 & 0,3252 & 0,0436 \\
2002 & 0,3273 & 0,0438 \\
2003 & 0,3253 & 0,0435 \\
2004 & 0,3263 & 0,0435 \\
2005 & 0,3340 & 0,0443 \\
2006 & 0,3400 & 0,0446 \\
\hline
\end{tabular}

Forrás: Saját szerkesztés.

Emellett a bruttó hazai termék és a foglalkoztatottak térbeli agglomerálódását számszerűsítettük Lorenz-görbe, Gini-mutató és Herfindhal-Hirschman-index segítségével. Az eredmények mind a GDP, mind az aktív népesség megoszlásában a központi térségek fokozódó szerepét mutatták, különösképpen a kilencvenes évek második felében és a visegrádi országok európai uniós csatlakozását követöen. 
Mindezek alapján kijelenthető, hogy az erőforrások koncentrációjának hipotézise megerösítést nyert.

A Visegrádi Négyek országaiban az átmenet idöszaka a termelés eröteljesebb, a munkaerö mérsékeltebb térbeli koncentrálódását eredményezte. Az agglomerálódást elöidézö erök intenzitása az 1990-es évek második felében és az európai uniós csatlakozást követöen fokozódott.

Az agglomerálódás folyamata elsödlegesen a fövárosok (Budapest, Prága, Pozsony, Varsó) és a lengyel regionális központok (Gdansk-Gdynia-Sopot, Krakkó, Lódz, Poznan, Wroclaw) gazdasági-társadalmi-tudományos súlyát és szerepét növelte. E növekedési pólusok a jövőben döntö hatást gyakorolhatnak a tágabb kelet-középeurópai térség gazdasági összteljesítményére, versenyképességére.

\section{Összefoglaló értékelés, javaslatok}

Munkánk elsődleges céljaként a gazdasági, politikai átmenet területi hatásainak vizsgálatát jelöltük meg. Választ kerestünk a Visegrádi Négyek térszerkezetében a választott évtizedben bekövetkezett változásokkal kapcsolatos kérdésekre. A választott négy ország (Csehország, Lengyelország, Magyarország, Szlovákia) példáján keresztül a nemzeti szintủ növekedés és a regionális konvergencia-divergencia közötti összefüggések feltárására, bemutatására és tudományos magyarázatára törekedtünk.

Kutatásunk eredményeivel összhangban javaslatokat fogalmaztunk meg a visegrádi országok makro- és mezoszintủ konvergenciája, valamint területileg kiegyensúlyozott, fenntartható fejlődése érdekében. A javaslatokat a klaszterelemzés eredményeként elöállt különböző térelemekre, régiócsoportokra szabtuk:

- A fövárosi térségek (,,abszolút nyertesek”) esetében a nemzetközi integráció, az európai és globális hálózatokba történő belépés élvez kiemelt prioritást.

- Ehhez szükséges, hogy minél több multinacionális és transznacionális vállalat, valamint nemzetközi szervezet települjön be a városokba vagy azok vonzáskörzetébe.

- A jövedelemtermelő képesség és a versenyképesség szempontjából kiemelt fontosságú a kutató-fejlesztó profil, az innovációs kapacitások további bővítése mind az infrastruktúra, mind az emberi erőforrás terén. Ennek érdekében elő kell segíteni az oktatási (elsődlegesen szak- és felsőfokú) intézmények nemzetközi presztízsének kialakitását, majd növelését.

- A fövárosi térségek infrastrukturális ellátottsága jónak mondható, azonban a vasúti hálózat amortizációja és a gyorsvasút-rendszer hiánya később szük keresztmetszetet okozhat a közlekedésben, szállításban. A nyugat-európai piacok elérése az autópályák, repülöterek által biztosított, azonban a hálózat fejlesztése szükséges a belső perifériák és a kelet-európai piacok irányában. Ezek a beruházások a centrumtérségek perifériákra gyakorolt jótékony (,spread") hatásainak erösítéséhez is elengedhetetlenek. 
- A másodlagos haszonélvezö (,,potenciális felzárkózó”) térségek számára a kialakult húzóágazatok, -telephelyek dinamizálása szükséges (kiváltképpen a jelenlegi válsághelyzetben).

- Ezért elsődlegesen a humán tőke fejlesztésének, valamint a tudás- és tőkeintenzív gyártási, termelési - leginkább a feldolgozóiparban - beruházásoknak az igénye jelentkezik. Ezek az intézkedések hozzájárulnak a regionális versenyképesség és a tőkevonzó-képesség javulásához, illetve a külkereskedelmi potenciál, az export volumenének fenntartásához, visszaszerzéséhez.

- A jövő szempontjából kardinális kérdés, hogy sikerül-e erösíteni a jövedelem- és munkaerö-megtartó képességet. A gyenge, kezdetleges $\mathrm{K}+\mathrm{F}$ infrastruktúra és az emberi erőforrás háttér fejlesztése, valamint a helyi gazdasági szereplök, vállalkozások klaszterekbe szervezése és azok müködtetése hatékonyan segítheti a fenti célok elérését.

- Az elmúlt két évtized alatt végbement nagymértékű differenciálódás negatív következményeinek tompítása, megszüntetése érdekében elengedhetetlen $a z$ átmenet vesztes régióinak (,,veszélyeztetett leszakadók”) segitése.

- Elsőbbséget kell, hogy élvezzen a munkaerö-piaci kondíciók javitása, a gazdasági aktivitás emelése. Ennek érdekében létfontosságú a munkaeröintenzív termelö ágazatok telepítése, valamint a mezögazdaság, illetve a vidék jövedelemtermelö-képességének fokozása.

- Az elérhetőség kérdése nem megoldott e régiók esetében („,keleti fal”), így reális a veszélye a gazdasági-társadalmi marginalizálódásnak, elszigetelődésnek. Ennek elkerülése, illetve az EU keleti határán egyfajta hídföszerep betöltése érdekében a közlekedési és telekommunikációs infrastruktúra fejlesztése szükséges. Mivel ezek a veszélyeztetett régiók több esetben nem rendelkeznek növekedési pólussal, az elérhetőség javítása a távolabbi nemzeti központok irányában is fontos.

- A helyi gazdaságok modernizációja és szerkezetváltása, a szolgáltatások minőségének javítása végett elengedhetetlen $a K+F$ tevékenységek és források, valamint a müködőtőke orientálása a térségbe.

A területi egyenlőtlenségek és a regionális konvergencia folyamatok elemzését az 1995-től 2006-ig tartó időtávon végeztük. A mezoszintủ adatok hiánya miatt nem volt lehetséges a 2006-ot követő esztendők számszerü vizsgálata. Ennek ellenére, vagy talán éppen ezért, fontosnak ítéljük, hogy nevesítsünk néhányat azon tényezők közül, amelyek az azóta eltelt időszakban befolyásolhatták a visegrádi országok régióinak fejlődését.

Időrendben haladva, először Románia és Bulgária 2007 eleji európai uniós csatlakozását emeljük $k i$, amely újabb fontos mérföldkő volt Köztes-Európa politikai és gazdasági integrációjának folyamatában. A két délkelet-európai állam belépése közvetlenül a Romániával határos Magyarországra, annak keleti régióira gyakorol hatást. Közvetetten azonban Köztes-Európa teljes makrorégiójára is, hiszen tovább növeli az 
újonnan csatlakozott államok súlyát az Unión belül. Lényegi elem, hogy ezen országok - a történelmi sérelmeken túllépve - belássák érték- és érdekközösségüket.

A 2007-es esztendő másik fontos eseménye volt, hogy decemberben a visegrádi országok is tagjai lettek az ún. schengeni övezetnek. A határellenőrzés „,megszünése” hozzájárul a regionális kölcsönhatások és kapcsolatok erősödéséhez, valamint a tényezők szabadabb áramlásához.

Végül, de nem utolsósorban a 2008 negyedik negyedévében kirobbanó világméretü hitelválságot nevezzük meg. A krízis negatív hatásai gyorsan és nagy intenzitással érték el a gazdaságilag nyitott és központi költségvetés helyzete szempontjából instabil visegrádi országokat. A válság - hasonlóan 1929-hez és 1973-hoz - két mechanizmus mentén érinti kritikusan Kelet-Közép-Európát. Az egyik a nyugati piacok beszükülése, ezáltal az export-lehetőségek csökkenése, amely negatívan hat a munkaerőpiacra és a jövedelmi színvonalra. A másik a tőkekivonás, illetve a térségbe beáramló FDI-volumen nagyságának csökkenése. Ezek a folyamatok elsődlegesen az export-orientált gazdasággal rendelkező régiókat érintik, de idővel tovagyürüznek az alárendelt térségekre is. Várhatóan a fejlettségi diszparitások mégsem csökkennek szignifikánsan, mivel a fővárosi térségek gazdaságát, társadalmát kevésbé érinti negatívan a recesszió, mint a perifériákét.

Zárszóként a politikai hatalom decentralizációjának fontosságára hívjuk fel a figyelmet. Ez a hosszadalmas folyamat, amely a visegrádi országokban rendkívül óvatosan indult meg, a régiók számára is pozitív politikai és gazdasági hozadékokkal járhat. Hiszen a nagyobb szabadságfokú helyi döntéshozatal lehetőséget kínál a civil társadalom erősítésére, a demokratikus rendszer bővítésére, valamint a gazdag történelmi múlt, a kulturális örökség és a kisebbségek védelmére. Ezek a tényezők pedig garanciát jelenthetnek a visegrádi országok régióinak, népeinek harmonikus, komplementer jellegü fejlődésére.

\section{Irodalom}

Barro, J.R. (2005) A gazdasági növekedést meghatározó tényezök. Közgazdasági Kiskönyvtár, Nemzeti Tankönyvkiadó, Budapest.

Benedek J. (2000) A társadalom térbelisége és térszervezése. Risoprint, Kolozsvár.

Dusek T. (2004) A területi elemzések alapjai. ELTE Regionális Földrajzi Tanszék, Budapest.

Edwards, M.E. (2007) Regional and Urban Economics and Economic Development (Theory and Methods). Auerbach Publications, New York.

European Commission (2008) Regions of the European Union - A Statistical portrait. European Commission, Luxembourg.

Fenyővári Zs.-Lukovics M. (2008) A regionális versenyképesség és a területi egyenlőtlenségek kölcsönhatásai. - Tér és Társadalom. 2. 1-20. o.

Fujita, M.-Krugman, P.-Venables, A. J. (2001) The Spatial Economy - Cities, Regions and International Trade. MIT Press, London-Cambridge.

Gilpin, R. (2004) Nemzetközi politikai gazdaságtan. Bucipe, Budapest.

Illés I. (2002) Közép- és Délkelet-Európa az ezredfordulón. Dialóg Campus Kiadó, Budapest-Pécs.

Illés I.(2008) Regionális gazdaságtan - területfejlesztés. Typotex, Budapest.

Kocziszky Gy. (2007) Regionális gazdaságtan. Miskolci Egyetem, Miskolc.

Kocziszky Gy. (2008) Terïletfejlesztés módszertana. Miskolci Egyetem, Gazdaságtudományi Kar, Miskolc.

Kozma G. (2006) Regionális Gazdaságtan. Kossuth Egyetemi Kiadó, Debrecen. 
Lengyel I.-Rechnitzer J. (2004) Regionális gazdaságtan. Dialóg Campus Kiadó, Budapest-Pécs.

Maurel, M.-C. (2006) Területi egyenlőtlenségek Európában, a bővítés mint a kohézió próbája. - Tér és Társadalom. 4. 169-182. o.

McCann, P.-Oort Van, F. (2009) Theories of agglomeration and regional economic growth: a historical review. - Capello, R.-Nijkamp, P. (eds.) Handbook of Regional Growth and Development Theories. Edward Elgar, Cheltenham-Northampton. 19-32. o.

Meyer, D.-Lackenbauer, J. (2006) Regional Policies and the Equity-Efficiency Trade-Off: Towards a Sequenced Timing of Cohesion Policy. - Acta Oeconomica. 3. 249-277. o.

Nemes Nagy J. (1998) A tér a társadalomkutatásban: Bevezetés a regionális tudományba. Hilscher R. Szociálpolitikai Egyesület, Budapest.

Nemes Nagy J. (szerk.) (2005) Regionális elemzési módszerek. ELTE Regionális Földrazi Tanszék, Budapest.

Novák G.-Papdi Á. (2007) Gazdasági egyenlőtlenségek a kibővült Európai Unióban. - Területi Statisztika. 6. 571-585. o.

Ottaviano, G.-Thisse, J-F. (2004) New economic geography: what about the N? CORE Discussion Papers 2004065. Université catholique de Louvain, Center for Operations Research and Econometrics (CORE), Louvain.

Pike, A.-Rodríguez-Pose, A.-Tomaney, J. (2008) Local and Regional Development. Routledge, London. United Nations (2002) World Urbanization Prospect The 2001 Revision. United Nations, New York.

Varga A. (2009) Térszerkezet és gazdasági növekedés. Akadémiai Kiadó, Budapest.

Williamson, J.G. (1965) Regional Inequality and the Process of National Development: a Description of the Patterns. Economic Development and Cultural Change. University of Chicago, Chicago.

World Bank (2009) World Development Report - Reshaping Economic Geography. World Bank, New York. 


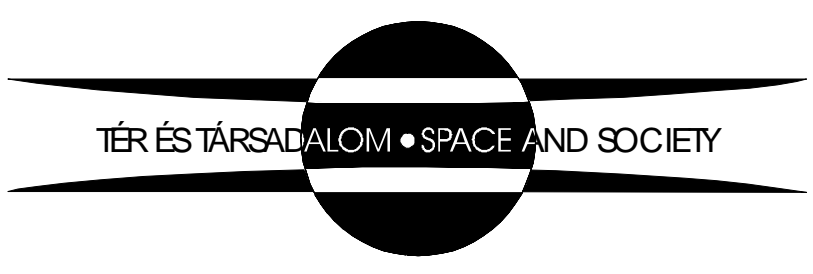

